\title{
RUSSIAN DISINFORMATION AND PROPAGANDA IN THE POLISH INFOSPHERE - CONTEXT OF THE COVID-19 PANDEMIC
}

UDC 327.5

\author{
Michał Marek - \\ $\mathrm{PhD}$ student, Jagiellonian University \\ (Krakow, Poland) \\ ORCID: 0000-0002-5085-4616
}

The publication addresses the issue of stimulation through private media companies and foreign entities of anxiety and social tensions on the wave of the Covid-19 pandemic. The publication presents the process of influence of environments permanently involved in the process of disinformation, in activities serving to intensify social polarization and the effects of the crisis as a result of activity in the Internet space. An important element of the publication is to indicate the relationship between the described centers of influence spreading harmful content and their participation in the popularization of content convergent with the messages of Russian disinformation centers. The presented material is based on the analysis of content posted by portals identified as permanently involved in the process of popularization of Russian disinformation narratives. The aim of the article is to show the threat to social order resulting from the activities of unrestricted alternative portals influencing, among other things, social networks. The activity of the indicated environments, which seem to be partially copying the Russian information agenda, is shown as an element of activities destabilizing the modern country and society. The paper lists the specific aspects influenced by these environments, and emphasises the connection between these aspects and the goals of Kremlin policy (specific narratives and the goals they are supposed to pursue are indicated). Portals and examples of publications are also listed. The analysis aims to identify the threat to contemporary European society posed by the lack of adequate country control over the Internet (especially social networks) - this issue is examined in the context of attempts to exploit this condition by an external factor for hostile activity.

Keywords: disinformation, Russian propaganda, Covid-19, social resilience.

\section{Міхал Марек \\ РОСІЙСЬКА ДЕЗІНФОРМАЦІЯ ТА ПРОПАГАНДА В ПОЛЬСЬКІЙ ІНФОСФЕРІ - КОНТЕКСТ ПАНДЕМІЇ COVID-19}

Дослідження присвячено темі стимулювання суспільного занепокоєння та напруженості приватними медіакомпаніями та іноземними організаціями у контексті пандемії Covid-19. Висвітлено вплив медіаресурсів, які постійно беруть участь у процесі дезінформації та заходах, спрямованих на поглиблення соціальної поляризації та посилення наслідків кризи у суспільстві. Важливим елементом публікації є загострення уваги на взаємозв'язку між описаними центрами впливу, котрі поширюють шкідливий контент, та їх участю в популяризації контенту, що відповідає наративам російських центрів дезінформації. Представлений матеріал базується на аналізі 
контенту, розміщеного порталами, які визначені як такі, що постійно залучені до процесу популяризації російських дезінформаційних наративів. Метою статті є привернути увагу до загрози соціальному порядку, що виникає внаслідок необмеженої діяльності альтернативних порталів та соціальних мереж. Діяльність зазначених кіл, яка, здається, частково дублює російський інформаційний порядок денний, буде представлена як елемент дій, що дестабілізують сучасну державу та суспільство. У публікації зазначено конкретні аспекти, на які впливають такі сайти та осередки впливу. Крім того, наголошується на зв'язку між цими аспектами й цілями політики Кремля. Аналіз зосереджено на тому, щоб вказати на загрозу для сучасного європейського суспільства, спричинену відсутністю належного державного контролю над інтернет-простором (особливо в соціальних мережах). Це питання вивчається в контексті спроб використання пандемії Covid-19 у якості зовнішнього фактору для проведення ворожої діяльності.

Ключові слова: дезінформація, російська пропаганда, Covid-19, стійкість.

The time of the Covid-19 pandemic and related social and economic processes have highlighted the extent to which contemporary society is susceptible to misinformation. The pandemic also highlighted the threats to country institutions due to increased disinformation activity by domestic and foreign actors. This study analyzes the latest activities of propaganda centers actively lobbying for content convergent with Russian propaganda. The research has been carried out in order to identify and describe the current trend, which seems to be stimulated by Russian centers of influence to achieve the goals of the Kremlin. We analyze actions of the Russian party relating to the Polish Internet space and activity of environments and platforms which openly or disguised undertake actions detrimental to the social order. On the basis of an analysis of the content of publications and materials distributed by the identified centers over a period of several months, conclusions relevant to understanding the ways in which the Kremlin influences Polish and Central European societies are presented.

Due to the Kremlin's relatively limited ability to influence the Poles, which results, among other things, from the lack of functioning Russian television in the country and the lack of general knowledge of the Russian language (which makes it impossible to influence the audience's perception through the use of Russian-language media networks), Moscow has been forced to adapt to conditions unfavorable from its point of view. The most effective form of building its network of influence centers seems to be through the Internet [1, p. 177; 2, p. 7]. The Russian party has had a network of alternative portals operating in Poland for many years, distributing narratives which are consistent with the Kremlin's interests. The messages created are shared using active groups in social networks, which are open to Russian messages. Published content is supported by the involvement of the so-called trolls and bot accounts [3, p. 85]. At the same time, there are openly pro-Russian portals and groups coordinated by per- sons «sympathetic» to the Russian party. Trends in the pro-Russian information agenda are also determined by the Sputnik portal operating in Poland, which is a platform where leaders of given environments publish and who legitimize Russian messages.

The pandemic period has drawn public attention to a number of problems related to the health, economic, and political situation. In the face of the threat to the health of citizens and the problems arising from the restrictions on the functioning of society, there has been a widespread increase in the sense of threat and an increase in social discontent, which is associated with the blocking of certain sectors of the economy. Citizens of European countries, among others, have found themselves in a crisis situation that is unprecedented in modern Western societies. Communication between governments/institutions and citizens became an important element of stabilization efforts. Not always consistent and clear communication from the authorities caused a part of society to doubt official messages. The undermining of official messages and messages of key media was facilitated by the global trend of low trust in classical media and the growing importance of para-media developing, among others, in the sphere of social networks. The trend is manifested by a common social problem of identifying trustworthy sources of information [4].

Another negative factor is the problem of the perceived limitation of media awareness of their responsibility for the popularized message (specificity of communication in crisis situations) [5, p. 74]. The time of crisis, as a result of many factors which will be discussed below, manifested itself in media chaos, which resulted, among other things, from the lack of constant and uniform construction of messages by political centers and key media [6]. This situation was intensified by the activity of media centers with relatively low popularity which, seeing an opportunity to increase their popularity, decided to popularize controversial content that 
attracted the attention of the audience. Unfortunately, such content often contributed to increased social polarization and tensions. This kind of activity is in the context of threats resulting from information wars taking place in the modern world [7, p. 14].

In connection with the crisis caused by the Covid-19 pandemic, centers permanently engaged in dissemination of disinformation and formation of communities believing in conspiracy theories began active production of messages fueling anti-vaccination and anti-government sentiments based on the myth of a «global conspiracy» aimed at bringing about the so-called «new order» («new world order»). Taking advantage of the crisis, these environments (broadcasting their message through alternative portals) have focused on attracting new message audiences (increasing their reach) by producing newer publications and audiovisual materials lobbying for more and more elaborate and absurd narratives. Centers involved in the popularization of Russian propaganda narratives played a unique role in the creation and dissemination of content undermining the sense of fighting the effects of the pandemic and content stimulating social unrest.

The activities of alternative portals permanently involved in the distribution of materials stimulating destabilization of the socio-political situation and the Polish version of the Russian portal «Sputnik» were focused on the following directions:

Stimulation of protests, anti-government speeches, and social polarization (including building a positive image of protesters and communities - creating a positive term for «civil disobedience».

- Building a negative image of the West and Western vaccines (spreading anti-vaccine panic - creating Western vaccines as part of efforts to control or exterminate humanity).

- Lobbying a positive image of Russia based on the theme of the Russian vaccine «Sputnik V». The vaccine was presented as extremely effective and "gaining popularity».

Undermining trust in country institutions and classical media (suggesting that the media and country institutions are involved in a global conspiracy - deceiving the citizens), and also depreciating the image of key political forces and supporting political parties and environments with political ambitions of the so-called' anti-system character', whose demands include lifting of sanctions imposed on the Russian Federation.
In the face of the pandemic, stimulating anti-governmental sentiments and building a positive image of the protesters (e.g. against «plandemics» - The term «plandemic» refers to an "planned» pandemic - one of the conspiracy theories.) is a harmful form of activity for these environments. It is worth remembering that protests and mass speeches are a factor that certainly does not positively influence the issue of limiting the effects of the pandemic. Both alternative portals involved in the process of popularizing Russian messages and the Russian portal «Sputnik» provide a platform that actively reports on anti-government protests of an anti-vaccine nature or those undermining the sense of the fight against the pandemic. While building their messages, both alternative portals involved in the disinformation process and portal «Sputnik» also focused on portraying the protests as "pro-freedom», «civic» initiatives, which are something bordering on the duty to fight against "pandemic totalitarianism». As examples of this kind of publications we can consider: «Demonstration «Let's go for freedom!» in Warsaw video» (portal «Sputnik»); «Numerous protests in Europe against Covid totalitarianism» (portal «ZmianyNaZiemi»); "Góralskie Veto. Grzegorz Braun: Now or never! Finally the knights came out from Giewont» (portal of «Najwyższy Czas») [8; 9]. The last of these publications refers to protests organized by a self-proclaimed leader of the inhabitants of a mountainous region in southern Poland (Podhale) against restrictions on tourism. To build these messages, statements were used, among others, by a member of the Polish Parliament, Grzegorz Braun («Konfederacja» party), who actively supports initiatives that undermine the fight against the Covid-19 pandemic.

Similarly, an exceptionally harmful form of action, similar to that indicated above, is the lobbying of conspiracy theories relating to the vaccine issue. Concentration of environments popularizing theories convergent with the Russian propaganda on broadcasting materials creating vaccines (Pfizer and AstraZeneca) as an element involved in the plan to "chip» humanity (gain control over it) or «murder it» contributes to the growth of anti-vaccine sentiments. Messages referring to a global conspiracy to destroy or invigilate society are extremely popular in the social networking space. Numerous groups that have so far engaged in self-disinformation regarding the alleged threat of $3 \mathrm{G}, 5 \mathrm{G}$, so-called chemtrails, etc. have focused on combining previous narratives with pandemic themes - for example, they have created narratives according to which the pandemic was caused by $5 \mathrm{G}$ transmitters. Publications on such topics, again en masse, began to create portals involved in lobbying messages that coincided with Russian propagan- 
da. As examples of the popularization of harmful messages relating to this topic, one should consider publications such as: «Bill Gates will spray chemicals from planes. It may lead to a catastrophe» (the portal of «Najwyższy Czas»); «They have enchained people in the USA and then tortured them!» (portal «Neon24») [10;11]. Such actions are combined with the production of less «radical» messages (e.g. mass distribution of false information about deaths among vaccinated people - «URGENT! A man died one day after receiving the vaccine!» (the portal «Prawy.pl») have influenced the formation of serious groups of people who, believing in false messages, popularize among their friends and loved ones the belief that vaccines should be rejected [12]. The strengthening of anti-vaccine sentiments forms the basis for the formation of anti-vaccine protests (of an anti-governmental nature). In addition, these actions affect the negative attitude of people towards the possibility of vaccination - this, in turn, may generate greater effects of the pandemic (more sick, more dead and a longer period of blocking the economy).

Parallel to the activities aimed at building a negative image of Western vaccines, the discussed sources build a neutral and even positive image of the Russian vaccine. All the negative features that are attributed to vaccines refer to Western products - especially the Pfizer product is demonized. Resulting from the actions of the Russian centers, which are directed against Ukraine, the lobbying of the positive image of the Russian vaccine «Sputnik V» has the character of preparations for stimulating social ferment against the Polish government, which in the face of the crisis will not decide to purchase this vaccine. While in case of Ukraine, the Russian party has taken active measures to build a negative image of V. Zelensky, creating him as a «Russophobe», who despite the «critical situation» of the pandemic in Ukraine, rejects the «Russian offer», in the case of Poland, similar measures are a form of preparing the base for potential analogous actions. The following articles can be cited as examples of building a positive image of the «Sputnik V» vaccine: "Polish doctor talking about the Russian vaccine: It proves effective, negotiations with Russia should be considered» (portal «Sputnik»), or «Israel will not disdain the Russian vaccine Sputnik V, because it can be a good business» (portal «Najwyższy Czas») $[13 ; 14]$.

The messages broadcasted by the above mentioned sources are reinforced by the content which reproduces the public resentment towards the government and the key political parties. The current government is portrayed as actively participating in a "global conspir- acy», or as a political force bringing together people of extremely low competence. For a long time, environments associated with portals permanently involved in the disinformation process have been creating key political forces and the government as 'puppets' of the USA or Germany (EU). In the course of constructing narratives related to the Covid-19 pandemic, these plots are expanded to include the alleged subordination of Polish political environments to American medical corporations, and even to the "Jewish business and political elites» directing the plan for the destruction of humanity in the push for an allegedly false pandemic. The broadcasting of such messages is often combined with lobbying for the supposedly only «truly Polish», «anti-system» party of «Konfederacja». Activities in this direction, in addition to the features of pure disinformation, have the character of influence on the electoral preferences of the recipient of the message. Example publications: «Braun talking about Niedzielski and Morawiecki. "Criminals responsible for the ruin of the Polish economy [VIDEO]». (portal «Najwyższy Czas»); «Politicians under the pretext of a pandemic rob us. Do Poles go to war with the government?» (portal of «NDZ») [15; 16].

The above-mentioned environments, associated around the portals indicated in the examples, constitute a network of sources duplicating each other's messages. Lobbied messages of propaganda and disinformation affect the spread of social unrest and destabilize the socio-political situation. Platforms such as YouTube or Facebook have become, in the face of Covid-19, a «tribune» where a difficult to stop, self-reinforcing wave of disinformation takes place. The benefits of this situation have been clearly perceived by Moscow, which, using its information capabilities and through its centers of influence, strengthens the disinformation process by popularizing information that serves the Kremlin's goals. The crisis caused by the Covid-19 pandemic revealed the problem with the power of social networks and often anonymous sources (e.g. alternative portals), which in favourable conditions are able to strengthen processes that are unfavourable for the country [17, p. 159]. It is worth remembering that a serious part of these sources, as a result of long-term detrimental actions, can be identified as environments permanently involved in broadcasting content convergent with Russian propaganda (e.g. copying Russian narratives stimulating anti-American, anti-NATO, anti-Ukrainian, anti-European and pro-Russian sentiments). Increased disinformation activity of these environments in the time of crisis stimulates reflection on taking necessary steps to build social resistance to the interference of an external factor in the infosphere of our countries. In case 
of Poland, the Internet space remains a key element of the infosphere, which the Kremlin is trying to influence. The hard-to-control areas of social networks and online platforms such as YouTube remain an ideal tool for external actors to direct the mood of contemporary society. The conclusions that we receive as a result of the analysis of processes indirectly related to the pandemic crisis should open us up to a calm debate on the topic of introducing mechanisms related to attempts to control the indicated «tools».

As a result of the fact that experts, social activists and the Polish state apparatus perceives the threat of the russian disinformations activities, new analytical centers and platforms for identifying propaganda and false content are emerging in Poland. Influence on Polish society conducted by NGO centers and private entities is manifested through active work with Polish content recipients through published analyzes and expert comments. Suitable and useful materials are shared in social networks, increasing the level of understanding of problem of the disinformation. The authorities of the Polish state, including the services, are also undertaking the fight against disinformation. One of examples is the activity by publishing mate- rials informing citizens about the current disinformation campaigns conducted by the Russian side on the pages of the government portal «gov.pl». Those publications are distributed by nationwide media. The services activity is also manifested by neutralizing the harmful influence of Russian agents of influence - Russian journalists accused, inter alia, of for obtaining information that the Kremlin uses to conduct anti-Polish disinformation operations (expulsion from the country of Leonid Sviridov and Jevgenij Reshetiev).

The Polish state, individually and in cooperation with NATO and EU structures, as well as activists and experts, take steps to increase the resilience of Polish society to disinformation by acting, inter alia, in the field of education. The issue of counteracting disinformation by the structures of the Polish state, private entities and NGOs however, requires, a completely separate analysis. The current experience proves, that from the perspective of counteracting propaganda and disinformation, an important aspect still is a social education and the introduction of the problem of the threat posed by disinformation for democratic society to the national information agenda.

\section{References}

1. Świątkowska, J. (2017). Wykorzystanie cyberprzestrzeni w walce hybrydowej na Ukrainie - wnioski dla Polski. In Konflikt hybrydowy na Ukrainie: aspekty teoretyczne i praktyczne / redakcja naukowa Bogusław Pacek, Julia Anna Grochocka. Piotrków Trybunalski : Uniwersytet Jana Kochanowskiego, p. 168-192 [in Polish].

2. Dacenko, A. Y. (2018). European experience in countering Russian disinformation during the Second Cold War. International Relations. Series: Political Science, 18/19, 7. journals.iir.kiev.ua. http://journals.iir.kiev.ua/index.php/ pol_n/article/viewFile/3381/3059 [in Ukrainian].

3. Savitski, K. (2016). Constructing mass media view of the dangers of information security of Poland. Media. Information. Communication. International Electronic Journal, Issue 18, p. 85. mic.org.ru. http://mic.org.ru/ phocadownload/18-savicky.pdf [in English].

4. Edelman Trust Barometer 2021. Globab Report. (2021, January). edelman.com. Retrieved February 1, 2021, from https://www.edelman.com/sites/g/files/aatuss191/files/2021-01/2021-edelman-trust-barometer.pdf?fbclid=IwAR2 ZNxC7bU75v6HsdtECD1J-2Yc5NSe-34AYmxtFrCd7iEkCAz1_ 1WnLCI [in English].

5. Buromenskyi, M., Shturcheckyi, S., Bliz, E., Betz, M., Shchupp, K., \& Kazanzhy, Z. (2016). Conflict Journalism: Best Practices and Recommendations. Kyiv: Kompania «VAITE», 118 p. [in Ukrainian].

6. Wirus, wirus wszędzie! Jak dezinformacyjne narracje pokazaly nasze słabości? (n.d.). cyberdefence24.pl. Retrieved February 1, 2021, from https://www.cyberdefence24.pl/wirus-wirus-wszedzie-jak-dezinformacyjne-narracjepokazaly-nasze-slabosci?fbclid=IwAR2Zgt5ucV9fyNnI1YXEvKsNNDwrS7QmUazdBsRZVNdIDNzQQUhOlfIHYHs [in Polish].

7. Malyk, Ya. (2015). Information war and Ukraine. Democratic Governance, Issue 15, p. 14. lvivacademy.com. http:// lvivacademy.com/vidavnitstvo_1/visnyk15/fail/Malyk.pdf [in Ukrainian].

8. Liczneprotestyw Europieprzeciwko Covidowemu totalitaryzmowi.(n.d.).zmianynaziemi.pl. Retrieved February 1,2021, from https://zmianynaziemi.pl/wiadomosc/liczne-protesty-w-europie-przeciwko-covidowemu-totalitaryzmowi [in Polish].

9. «Góralskie Veto». Grzegorz Braun: Teraz albo nigdy! Spod Gewontu wreszcie wyszli rycerze. (2021, January 16). Najwyższy Czas. Retrieved February 1, 2021, from https://nczas.com/2021/01/16/goralskie-veto-grzegorz-braunteraz-albo-nigdy-spod-gewontu-wreszcie-wyszli-rycerze/ [in Polish]. 
10. Bill Gates będzie rozpylat chemikalia z samolotów. Może doprowadzić do katastrofy. (2020, July 19). Najwyższy Czas. Retrieved February 1, 2021, from https://nczas.com/2020/07/19/bill-gates-bedzie-rozpylal-chemikalia-zsamolotow-moze-doprowadzic-do-katastrofy/ [in Polish].

11. Garland, T. (n.d.). Zaczipowali ludzi w USA, a potem ich torturowali. teresagarland.neon24.pl. Retrieved February 1, 2021, from https://teresagarland.neon24.pl/post/157430,zaczipowali-ludzi-w-usa-a-potem-ich-torturowali [in Polish].

12. PILNE! Mężczyzna zmarł dzień po podaniu szczepionki! (n.d.). prawy.pl. Retrieved February 1, 2021, from https:// prawy.pl/112511-pilne-mezczyzna-zmarl-dzien-po-podaniu-szczepionki/ [in Polish].

13. Polski lekarz o rosyjskiej szczepionce: Okazuje się skuteczna, należy rozważyć negocjacje z Rosją. (2020, February 3). pl.sputniknews.com. Retrieved February 1, 2021, from https://pl.sputniknews.com/polska/2021020313768133polski-lekarz-o-rosyjskiej-szczepionce-okazuje-sie-skuteczna-nalezy-rozwaz-negocjacje-z-rosja/ [in Polish].

14. Izrael nie pogardzi rosyjska szczepionką Sputnik V, bo może to być dobry interes. (2020, November 22). Najwyższy Czas. Retrieved February 1, 2021, from https://nczas.com/2020/11/22/izrael-nie-pogardzi-rosyjska-szczepionkasputnik-v-bo-moze-to-byc-dobry-interes/ [in Polish].

15. Przestępcy, którzy odpowiadają za ruinę polskiej gospodarki [WIDEO]. (2021, January 13). Najwyższy Czas. Retrieved February 1, 2021, from https:/nczas.com/2021/01/13/braun-o-niedzielskim-i-morawieckim-przestepcy-ktorzyodpowiadaja-za-ruine-polskiej-gospodarki-wideo/ [in Polish].

16. Politycy pod pretekstem pandemii okradaja nas. Polacy ida na wojnę z rządem? (2021, January 25). dziennik-polityczny. com. Retrieved February 1, 2021, from https://dziennik-polityczny.com/2021/01/25/politycy-pod-pretekstempandemii-okradaja-nas-polacy-ida-na-wojne-z-rzadem/ [in Polish].

17. Korol, L. M., \& Maksymets, S. M. (2014). Psychological factors of influence of mass media on formation of the personality of modern youth. Nauka ta osvita, 5, 157-162. core.ac.uk. https://core.ac.uk/download/42971030.pdf [in Ukrainian]. 